\title{
PRESENCE OF CAMPYLOBACTER AND SALMONELLA SPP. IN POULTRY AND ENVIRONMENTAL SAMPLES FROM FARM TO RETAIL IN HUNGARY
}

\author{
D. Tözsér*, K. Szakmár, R. Szima, O. Erdősi, Zs. Szili and P. Laczay \\ Department of Food Hygiene, University of Veterinary Medicine, H-1078 Budapest, István u. 2. Hungary
}

(Received: 25 March 2019; accepted 23 May 2019)

\begin{abstract}
The aim of this study was to investigate the occurrence of Salmonella enterica and its most important serovars Salmonella Infantis, Salmonella Enteritidis, Salmonella Typhimurium, and Campylobacter spp. in the broiler meat production chain. Altogether 110 pooled samples were analysed; environment, cloaca, body surface at the farm, then carcass, offal, and packed meat from the slaughterhouse. The combination of redox potential measurement and realtime PCR was used for the detection of the microbes.

At the farm, the first Salmonella positive result came from the water system, then it appeared in most of the samples. In contrast to the absence of Salmonella on the birds' body surface before transportation, by the end of the processing it had reached $100 \%$, with the only identifiable serovar being $S$. Infantis $(65 \%)$. All packed meat samples showed positivity, from which $70 \%$ was $S$. Infantis.

Campylobacter appeared at the farm on the $3^{\text {rd }}$ week and remained significant during the breeding. After the slaughtering process, the contamination was $100 \%$ in the carcass, offal, and packaged meat samples.

Our results demonstrated the success of the Salmonella control program, by the low prevalence of $S$. Typhimurium and Enteritidis.
\end{abstract}

Keywords: Salmonella, Campylobacter, poultry, food safety, public health

Campylobacter has been the most commonly reported gastrointestinal bacterial pathogen in humans in the European Union since 2005 (EFSA, 2017). Broiler meat is considered to be the most important source of human campylobacteriosis. Campylobacter genotypes found in the farm flock can efficiently survive and persist throughout the food chain (GRUNTAR et al., 2015). The number of Campylobacter found in the carcass varies during the processing; usually it is the highest at the defeathering, followed by a decrease along the rest of the steps (GuERIN et al., 2010). But the modern, short processing chain, the dark, moist, and cool storage, and the use of protective plastics contribute to Campylobacter survival, especially in large-scale marketing (HARRISON et al., 2001). High contamination level in meat preparations and meat cuts has been described by authors (HuMPhreY et al., 2007; SUZuKI \& YAMAMOTO, 2009). The infective dose of Campylobacter is low, so carcasses contaminated at low level can also be considered as threat to public health (RoBINSON, 1981; MALHER et al., 2011).

Since the implementation of the National Control Programmes, the declining trend in the prevalence of Salmonella Enteritidis and Salmonella Typhimurium positive poultry flocks has continued for all groups of animals during their production period in the EU. Salmonellosis, caused by Salmonella enterica is one of the most frequently reported foodborne illnesses worldwide. Chicken meat has often been reported as a source of Salmonella contamination (AlaLI et al., 2014). Salmonella Infantis and S. Enteritidis were the two most common serovars isolated from broiler meat in the European Union in 2016 (EFSA, 2017).

\footnotetext{
* To whom correspondence should be addressed.

Phone: +3614784177; e-mail: tozser.dora@univet.hu
} 
While Campylobacter and Salmonella infections are often asymptomatic in broilers, the colonization of these pathogens in broilers presents a significant risk to human health through ingestion of contaminated meat. Improving our understanding of the on-farm transmission dynamics of Campylobacter and Salmonella will allow the implementation of better control measures to reduce pathogen prevalence (THAKUR et al., 2013).

The aim of this study was to examine the prevalence of Campylobacter and Salmonella during the whole food chain. The birds, the environments of the farm, the slaughterhouse, and the processing plant were sampled to determine the spread and contamination possibilities of the two pathogens at the different stages.

\section{Materials and methods}

\subsection{Sample collection}

A total of 110 samples were examined between February and April 2017 in Hungary. The samples were collected from the two unseparated halves of a single building. Four feed, 4 bedding, 4 water, 5 cloaca, and 5 body surface samples were collected from both areas and then pooled into two final samples ('A' and ' $B$ ' building). The first sampling of the environment happened before the animals' arrival (day 0), then the broilers were sampled immediately after their settling. Afterwards, the same number of samples were taken every week on the same day until the chickens' transportation to the slaughterhouse; altogether 36 from the environment and 24 from the animals. Further samples were obtained on the day of slaughter $(n=20)$ and from the packaged meat $(n=30)$. The samples are summarised in Table 1.

Twenty five grams of meat samples were collected. The examination of the surfaces was carried out by swab and sponge sampling from a $100 \mathrm{~cm}^{2}$ area. Each sample was put into different sterile stomacher bags and transferred into the laboratory in a cooler box at $4{ }^{\circ} \mathrm{C}$. The analysis of the samples was performed on the same day.

Table 1. Sampling locations and sampling methods used in the study

\begin{tabular}{|c|c|c|c|c|}
\hline & Sampling location & Type of sample & Sampling method & Samples (n) \\
\hline \multirow[t]{5}{*}{ Farm } & Bedding & Faeces & $25 \mathrm{~g}$ & 12 \\
\hline & Cloaca & Faeces & Swab & 12 \\
\hline & Feed & Feed & $25 \mathrm{~g}$ & 12 \\
\hline & Drinking system & Surface & Sponge & 12 \\
\hline & Body surface & Surface & Sponge & 12 \\
\hline \multirow[t]{4}{*}{ Slaughterhouse } & Body surface before transport & Surface & Sponge & 5 \\
\hline & Body surface after evisceration & Surface & Sponge & 5 \\
\hline & Abdominal cavity & Surface & Sponge & 5 \\
\hline & Offals & Meat & $25 \mathrm{~g}$ & 5 \\
\hline \multirow[t]{5}{*}{ Retail } & MSM* & Meat & $10 \mathrm{~g}$ & 5 \\
\hline & Chicken breast filet & Meat & $25 \mathrm{~g}$ & 5 \\
\hline & Chicken wings & Meat & $25 \mathrm{~g}$ & 5 \\
\hline & Chicken back & Meat & $25 \mathrm{~g}$ & 5 \\
\hline & Drumstick & Meat & $25 \mathrm{~g}$ & 5 \\
\hline Total & & & & 110 \\
\hline
\end{tabular}

*MSM: mechanically separated meat 


\subsection{Detection of Salmonella}

The enrichment phase was carried out by redox potential measurement method. The redox potential measurement was originally developed for rapid determination of viable count of several microorganisms in water, milk, food, and hygienic samples (REICHART et al., 2007; ERDösI et al., 2012; 2014). As a result of the enrichment, the Salmonella positive samples could be detected by this rapid technique. Instead of a subsequent biochemical confirmation, further identification was carried out by applying real-time PCR technique (ERDősI et al., 2014).

Rappaport-Vassiliadis Salmonella selective broth (RVS broth) Merck 107666 was used as culture medium at the incubation temperature of $42^{\circ} \mathrm{C}$. Samples of $25 \mathrm{~g}$ were homogenized in $225 \mathrm{ml}$ of RVS broth. Swabs were placed into the measuring cell containing $10 \mathrm{ml}$ broth. The sponges were put into $100 \mathrm{ml}$ of selective medium.

During the incubation in water bath, the redox potential of each cell was continuously monitored. The parts of the redox potential measuring system were: Schott Blue Line 31RX redox electrodes, MicroTester device supplied with a Windows-based software MicroTester Redox v.2.5.16 for data collection and evaluation (REICHART et al., 2007).

DNA was isolated from $1 \mathrm{ml}$ of the enriched samples taken from the redox potential measuring cell at the end of the enrichment process. "Mericon DNA Bacteria Kit" (Qiagen) was used according to the manufacturer's instructions.

Real-time PCR amplification was performed on SLAN® Real-Time PCR System (Hongshi) using Mericon Salmonella Kit (Qiagen) for the detection of Salmonella spp. DiaSalmR kit (Diagon) was used in order to detect Salmonella Typhimurium, S. Enteritidis, and $S$. Infantis. PCR assays contained $10.8 \mu$ l Multiplex PCR Master Mix and 9.2 $\mu$ l DNA isolate.

\subsection{Detection of Campylobacter spp.}

Bolton Broth (Merck 100068) with Bolton Selective Supplement (Merck 100079) was used for selective enrichment.

Samples of $25 \mathrm{~g}$ and $225 \mathrm{ml}$ broth were put into $250 \mathrm{ml}$ measuring cells equipped with redox electrodes. Swabs and sponges were placed into the measuring cells containing $10 \mathrm{ml}$ and $100 \mathrm{ml}$ broth, respectively.

To verify the presence of Campylobacter spp., real-time PCR technique was used. Genomic DNA was isolated from $1 \mathrm{ml}$ of enriched samples. "MericonDNA Bacteria Kit" (Qiagen) was used according to the manufacturer's instructions. Real-time PCR amplification was performed with SLAN® Real-Time PCR System (Hongshi) using the Mericon Campylobacter spp. kit (Qiagen). The PCR tubes contained 10.8 $\mu 1$ Multiplex PCR Master Mix and 9.2 $\mu \mathrm{l}$ DNA isolate.

\subsection{Mathematical-statistical evaluation}

The regression analysis for the calibration curves was performed by Microsoft Excel 2016.

\section{Results and discussion}

\subsection{Salmonella}

The weekly changes of the presence of positive samples at the farm are shown in Table 2 . The bacterium first appeared at the $1^{\text {st }}$ week in the water sample similarly as described by other 
authors earlier in Spain (MARIN et al., 2011). Then, from the $2^{\text {nd }}$ week positive results were detected from all other materials, except for the feed (only a single positive sample at the $5^{\text {th }}$ week). $S$. Infantis and $S$. Typhimurium were identified by the real-time PCR. According to Regulation No 200/2012 (EU, 2012), the goal regarding broiler flocks is to reduce the prevalence of $S$. Enteritidis and/or $S$. Typhimurium to 1\%. The percentage of non-target serovars increased in 2015 due to $S$. Infantis (EFSA, 2017). Our findings were in correlation with the relevant EFSA report.

Table 2. Presence of Salmonella enterica at the broiler farm

\begin{tabular}{|c|c|c|c|c|c|c|c|c|c|c|}
\hline \multirow[t]{2}{*}{ Date } & \multicolumn{2}{|c|}{ Bedding } & \multicolumn{2}{|c|}{ Feed } & \multicolumn{2}{|c|}{ Drink } & \multicolumn{2}{|c|}{ Body surface } & \multicolumn{2}{|c|}{ Cloaca } \\
\hline & A & B & A & B & A & B & A & B & $\mathrm{A}$ & B \\
\hline Settling & - & - & - & - & - & - & - & - & - & - \\
\hline Week 1 & - & - & - & - & + & + & - & - & - & - \\
\hline Week 2 & + & + & - & - & $+\mathrm{SI}$ & $+\mathrm{SI}$ & $+\mathrm{SI}$ & $+\mathrm{SI}$ & + & $+\mathrm{ST}$ \\
\hline Week 3 & + & + & - & - & $+\mathrm{ST}$ & $+\mathrm{ST}$ & $+\mathrm{ST}$ & $+\mathrm{SI}$ & + & + \\
\hline Week 4 & + & + & - & - & + & + & + & + & $+\mathrm{ST}$ & $+\mathrm{SI}$ \\
\hline Week 5 & + & + & + & - & + & + & - & - & $+\mathrm{ST}$ & $+\mathrm{SI}$ \\
\hline
\end{tabular}

'A', 'B': pooled samples from the two unseparated areas of the building SI: Salmonella Infantis

ST: Salmonella Typhimurium

The $0 \%$ positivity from before the transportation increased up to $100 \%$ in the offal and on the body surface and $80 \%$ in the body cavity after the evisceration. Only serovar $S$. Infantis $(65.3 \%)$ was identified. The results of the slaughterhouse's sampling are found in Table 3 .

As can be seen, $100 \%$ of the samples taken from chicken meat packages were found positive, from which $70 \%$ was $S$. Infantis. $S$. Typhimurium and $S$. Enteritidis have not been detected (Table 4). Other authors have published Salmonella prevalence from samples taken from the skin of the skin-on chicken parts and the meat of the skin-off parts with $42.2 \%$ and $17.6 \%$, respectively (GURAN et al., 2017). More studies have determined the overall Salmonella presence on chicken carcasses and chicken parts around 30\% (MAZENGIA et al., 2014; Wu et al., 2014).

Table 3. Presence of Salmonella and Campylobacter spp. during the slaughtering process (\%)

\begin{tabular}{|c|c|c|c|c|c|}
\hline Sample & $\begin{array}{l}\text { Salmonella } \\
\text { spp. }\end{array}$ & $\begin{array}{l}\text { Salmonella } \\
\text { Infantis }\end{array}$ & $\begin{array}{c}\text { Salmonella } \\
\text { Typhimurium }\end{array}$ & $\begin{array}{c}\text { Salmonella } \\
\text { Enteritidis }\end{array}$ & Campylobacter \\
\hline $\begin{array}{l}\text { Body surface before } \\
\text { transport }\end{array}$ & 0 & 0 & 0 & 0 & 60 \\
\hline $\begin{array}{l}\text { Body surface after } \\
\text { evisceration }\end{array}$ & 100 & 70 & 0 & 0 & 100 \\
\hline $\begin{array}{l}\text { Abdominal cavity after } \\
\text { evisceration }\end{array}$ & 80 & 35 & 0 & 0 & 100 \\
\hline Offal & 100 & 91 & 0 & 0 & 100 \\
\hline
\end{tabular}


Table 4. Presence of Salmonella and Campylobacter in the packaged meat samples (\%)

\begin{tabular}{lccccc}
\hline Sample & $\begin{array}{c}\text { Salmonella } \\
\text { spp. }\end{array}$ & $\begin{array}{c}\text { Salmonella } \\
\text { Infantis }\end{array}$ & $\begin{array}{c}\text { Salmonella } \\
\text { Typhimurium }\end{array}$ & $\begin{array}{c}\text { Salmonella } \\
\text { Enteritidis }\end{array}$ & Campylobacter \\
\hline Wings & 100 & 44 & 0 & 0 & 100 \\
Thighs & 100 & 81 & 0 & 0 & 100 \\
Drumsticks & 100 & 81 & 0 & 0 & 100 \\
Breasts & 100 & 72 & 0 & 0 & 100 \\
Back & 100 & 62 & 0 & 0 & 100 \\
MSM & 100 & 80 & 0 & 0 & 100 \\
\hline
\end{tabular}

\subsection{Campylobacter spp.}

Several studies have revealed that Campylobacter contamination is higher in the chicken meat than that of Salmonella (HuANG et al., 2016).

Transmission along the food chain (from broilers, through the abattoir, to the retail shop) is generally accepted as a major source of human campylobacteriosis (THAKUR et al., 2010). Over the last decade, the prevalence of Campylobacter in the poultry production chain has been widely investigated in many countries. This was in agreement with previous studies that have determined that once Campylobacter enters a flock, it spreads quickly and colonizes the entire flock (THAKUR et al., 2013). Although strategies for reducing the incidence of this pathogen in poultry and poultry products are being studied and applied, the prevalence of Campylobacter is still high (Prachantasena et al., 2016).

In our study, the first Campylobacter positive samples were detected in the 3-week-old flock, when Campylobacter was isolated from the drinking system, bedding, and the surface of the animals. From the $4^{\text {th }}$ week of the examination, $100 \%$ of the cloaca samples became positive. The feed was proved to be negative throughout the whole experiment. The weekly changes of the presence of the Campylobacter positive samples at the farm are shown in Table 5.

Table 5. Presence of Campylobacter spp. at the broiler farm

\begin{tabular}{|c|c|c|c|c|c|c|c|c|c|c|}
\hline \multirow[t]{2}{*}{ Date } & \multicolumn{2}{|c|}{ Bedding } & \multicolumn{2}{|c|}{ Feed } & \multicolumn{2}{|c|}{ Drink } & \multicolumn{2}{|c|}{ Body surface } & \multicolumn{2}{|c|}{ Cloaca } \\
\hline & $\mathrm{A}$ & B & $\mathrm{A}$ & B & A & B & $\mathrm{A}$ & $\mathrm{B}$ & $\mathrm{A}$ & B \\
\hline Settling & - & - & - & - & - & - & - & - & - & - \\
\hline Week 1 & - & - & - & - & - & - & - & - & - & - \\
\hline Week 2 & - & - & - & - & - & - & - & - & - & - \\
\hline Week 3 & + & + & - & - & + & + & + & + & - & - \\
\hline Week 4 & + & + & - & - & + & + & - & - & + & + \\
\hline Week 5 & - & - & - & - & - & - & + & + & + & + \\
\hline
\end{tabular}

'A', 'B': pooled samples from the two unseparated areas of the building

The $60 \%$ positivity of the body surface before the transport has increased to $100 \%$ during the slaughtering process, indicating an important cross-contamination rate between poultry meat and the equipment (Table 3 ). Other authors have found around $50 \%$ positivity, showing the high prevalence of Campylobacter in the poultry production chain (SANCHEZ et 
al., 2017). PrachantaSENA and co-workers (2016) found a prevalence of $43.5 \%$ as an average of five slaughterhouses in Thailand. KUDIRKIENE and co-workers (2011) stated that Campylobacter can survive in the slaughterhouse for 8 hours. Their examinations showed that the processing area was less contaminated with $C$. jejuni than the slaughterhouse.

All 60 packed poultry meat samples exhibited positivity (Table 4). This is significantly higher than the results of other authors. The prevalence of Campylobacter in French retail is high, $76 \%$ of chicken meat products were found to be contaminated (GUYARD-NICODÉME et al., 2015). In Italy, STELLA and co-workers (2017) described $34.1 \%$ prevalence. In a previous research in Hungary, $76.4 \%$ positivity was described (DAmJAnOva et al., 2011).

\section{Conclusions}

Based on our results, the Salmonella control program in the EU is successful, because the prevalence of $S$. Enteritidis and Typhimurium serovars is low. However, the prevalence of other serovars, especially $S$. Infantis, which can cause similar symptoms in humans as $S$. Enteritidis and Typhimurium, has increased significantly.

An efficient control program should be applied to reduce the occurrence of other Salmonella serovars and Campylobacter spp. to decrease human foodborne diseases originated from the poultry production chain, with particular regard to the farm's water system and the hygiene of the slaughterhouse.

The $100 \%$ positivity of Salmonella and Campylobacter ssp. shows how important the consumers' awareness is during the processing and home cooking procedures of raw chicken products.

This research was supported by the 11475-4/2016/FEKUT grant of the Hungarian Ministry of Human Resources.

\section{References}

Alali, W.Q., Gaydashov, R., Petrova, E., Panin, A., Tugarinov, O. ... \& Doyle, M.P. (2014): Prevalence of Salmonella on retail chicken meat in Russian Federation. J. Food Protect., 75, 1469-1473.

Damjanova, I., Jakab, M., Farkas, T., Mészáros, J., Galántai, Zs. ... \& Kardos, G. (2011): From farm to fork follow-up of thermotolerant campylobacters throughout the broiler production chain and in human cases in a Hungarian county during a ten-months period. Int. J. Food Microbiol., 150, 95-102.

EFSA (2017): The European Union summary report on trends and sources of zoonoses, zoonotic agents and foodborne outbreaks in 2016. Available at https://efsa.onlinelibrary.wiley.com/doi/epdf/10.2903/j.efsa.2017.5077 (last accessed 19 March 2019)

Erdősi, O., Szakmár, K., Reichart, O., Székely-Körmöczy, P. \& Laczay, P. (2012): Application of the redox potential measurement based rapid method in the microbial hygienic control. Acta Alimentaria, 41, 45-55.

Erdösi, O., Szakmár, K., Reichart, O., Szili, Zs., LÁszló, N. ... \& LACZAY, P. (2014): Rapid detection of Salmonella in food by redox-potential measurement based method combined with real-time PCR. Acta Alimentaria, 43, $660-667$.

EU (2012): Commission Regulation (EU) No 200/2012 of 8 March 2012 concerning a Union target for the reduction of Salmonella enteritidis and Salmonella typhimurium in flocks of broilers, as provided for in Regulation (EC) No 2160/2003 of the European Parliament and of the Council (Text with EEA relevance).

Gruntar, I., Biasizzo, M., Kušar, D., PATe, M. \& OcePeK M. (2015): Campylobacter jejuni contamination of broiler carcasses: Population dynamics and genetic profiles at slaughterhouse level. Food Microbiol., 50, 97-101. 
Guerin, M.T., Sir, C., Sargeant, M.J., Wadell, L., O’connor, A.M. ... \& Byrd, J.A. (2010): The change in prevalence of Campylobacter on chicken carcasses during processing: a systematic review. Poultry Sci., 89, 1070-1084.

Guran, H.S., ManN, D. \& Alali, W.Q. (2017): Salmonella prevalence associated with chicken parts with and without skin from retail establishments in Atlanta metropolitan area, Georgia. Food Control, 73, 462-467.

Guyard-Nicodème, M., Rivoal, K., Houard, E., Rose, V., Quesne, S. ... \& Guilier, L (2015): Prevalence and characterization of Campylobacter jejuni from chicken meat sold in French retail outlets. Int. J. Food Microbiol., 203, 8-14.

Harrison, W.A., Griffith, C.J., Tennant, D. \& Peters, A.C. (2001): Incidence of Campylobacter and Salmonella isolated from retail chicken and associated packaging in South Wales. Lett Appl. Microbiol., 33, 450-454.

Huang, J., Zong, Q., ZhaO, F., Zhu J. \& JiAO, X. (2016): Quantitative surveys of Salmonella and Campylobacter on retail raw chicken in Yangzhou, China. Food Control, 59, 68-73.

Humphrey, T., O’Brien, S. \& Madsen, M. (2007): Campylobacters as zoonotic pathogens: A food production perspective. Int. J. Food Microbiol., 117, 237-257.

Kudirkienè, E., Bunevicienè, J., Brøndsted, L., Ingmer, H., Olsen J.E. \& Malakauskas, M. (2011): Evidence of broiler meat contamination with post-disinfection strains of Campylobacter jejuni from slaughterhouse. Int. J. Food Microbiol., 145, 116-120.

Malher, X., Simon, M., Charnay, V., Des Déserts, R.D., Lehébel, A. \& Belloc, C. (2011): Factors associated with carcass contamination by Campylobacter at slaughterhouse in cecal-carrier broilers. Int. J. Food Microbiol., $150,8-13$.

Marin, C., Balash, S. VeGa, S. \& LAINEZ, M. (2011): Sources of Salmonella contamination during broiler production in eastern Spain. Prev. Vet. Med., 98, 39-45.

Mazengia, E., Samadpour, M., Hill, H.W., Greeson, K., Tenney, K. \& LiaO, G. (2014): Prevalence, concentrations, and antibiotic sensitivities of Salmonella serovars in poultry from retail establishments in Seattle, Washington. J. Food Protect., 77, 885-893.

Prachantasena, S., Charununtakorn,P., Muangnoicharoen, S.,Hankla,L., Techawal, N....\&Luangtongkum, T. (2016): Distribution and genetic profiles of Campylobacter in commercial broiler production from breeder to slaughter in Thailand. PLoS One, 11, 1-16.

Reichart, O., Szakmár, K., Jozwiak, Á., Felföldi, J. \& Baranyai, L. (2007): Redox potential measurement as a rapid method for microbiological testing and its validation for coliform determination. Int. J. Food Microbiol., 114, 143-148.

Robinson, D.A. (1981): Infective dose of Campylobacter jejuni in milk. Brit. Med. J., 282, 584.

Sanchez, L.G., Melero, B., Jaime, I., HaAnninen, M.L., Rossi, M. \& Rovira, J. (2017): Campylobacter jejuni survival in a poultry processing plant environment. Food Microbiol., 65, 185-192.

Suzuki, H. \& Yамамото, S. (2009): Campylobacter contamination in retail poultry meats and by-products in the world: a literature survey. J. Vet. Med. Sci., 71, 255-261.

Stella, S., Soncini, G., Ziino, G., Panebianco, A., Pedonese, F. ... \& Giaccone, V. (2017): Prevalence and quantification of thermophilic Campylobacter spp. in Italian retail poultry meat: Analysis of influencing factors. Food Microbiol., 62, 232-238.

Thakur, S., Zhao, S., McDermott, P.F., Harbottle, H., Aвbott, J. ... \& White, D.G. (2010): Antimicrobial resistance, virulence, and genotypic profile comparison of Campylobacter jejuni and Campylobacter coli isolated from humans and retail meats. Foodborne Pathog. Dis., 7, 835-844.

Thakur, S., Brake, J., Keelara, S., Zou, M. \& Susick, E. (2013): Farm and environmental distribution of Campylobacter and Salmonella in broiler flocks. Res. Vet.Sci., 94, 33-42.

Wu, D., Alali, W.Q., Harrison, M.A. \& Hofacre, C.L. (2014): Prevalence of Salmonella in neck skin and bone of chickens. J. Food Protect., 77, 1193-1197.

Open Access statement. This is an open-access article distributed under the terms of the Creative Commons Attribution 4.0 International License (https://creativecommons.org/licenses/by/4.0/), which permits unrestricted use, distribution, and reproduction in any medium, provided the original author and source are credited, a link to the CC License is provided, and changes - if any - are indicated. (SID_1) 